\title{
THE EFFECTIVENESS OF THE ELECTROMAGNETIC FIELD MATRIX TO THE WOUND HEALING PROCESS IN PARTIAL - THICKNESS BURNS
}

\author{
Raminta Česnaitienè, Rytis Rimdeika \\ Hospital of Lithuanian University of Health Sciences Kaunas Clinics, \\ Plastic and Reconstructive Surgery Clinic
}

Keywords: burns, burns treatment, electromagnetic field treatment.

\section{Summary}

Burns are one of the most serious injuries, affecting around 11 million people a year worldwide. About 200/100000 inhabitants in Lithuania. Treatment is complex: the priorities of specialized facilities focus on stabilizing the patient, preventing infection, and optimizing functional recovery; and requires a lot of resources, both human and financial. Therefore, more and more effective treatments for burns are constantly being sought in order to accelerate the healing itself and thus reduce the duration of hospitalization. Number of recent reports suggests that EMF has a positive impact at different stages of healing. Processes impacted by EMF include, but are not limited to, cell migration and proliferation, expression of growth factors, nitric oxide signaling, cytokine modulation, and more.

Objectives and methods. The objective of this work was to study the effect of electromagnetic matrix on wound healing in burns. We evaluated medical records of 18 patients who underwent treatment in the department of plastic and reconstructive surgery from 2018.01.01 to 2019.12.30. All patients had IIA-IIB degree burns affecting less than $10 \%$ of the body surface and underwent the standard general treatment. They were divided into two groups: control group 55,6\% $(\mathrm{n}=10)$ - treated only with the standard treatment and research group $44,4 \%(n=8)$ - to whom the EMF matrix were applied. Statistical data analysis was carried out using the SPSS 23.0 software. Results. Pain assessment, wound granulation area, and epithelialization were chosen to evaluate the burn healing process. These indicators were assessed on day $0-1 ; 3( \pm 1)$ days and $7( \pm 1)$ days after hospitalization. There was a statistically significant increase in wound granulation 5 days after the start of treatment in patients treated with the applicator $(p=0.019)$. Pain and epithelialization rates between standard and applicator treatment methods did not differ statistically significantly over the treatment period. The partial nonparametric Spearman correlation coefficient, eliminating potentially influencing factors such as time after injury, the area of burn showed that the treatment method had a direct effect on the area of wound granulation $(\mathrm{r}=0.625 ; \mathrm{p}=0.04)$.

Conclusion. During the period from 2018.01.01 to 2019.12.31 patients had IIA-IIB degree burns affecting less than $10 \%$ of the body surface. $55,6 \%$ of patients were treated only with the standard treatment and $44,4 \%$ with EMF matrix. The analysis showed that the average hospitalization time of the control group was $8.5(0.898)$ days, while in the research group it was 7.88 (1.493) days, no statistically significant difference $(\mathrm{p}>0.05)$. There was a statistically significant increase in wound granulation 5 days after the start of treatment in patients treated with the applicator $(\mathrm{p}=0.019)$. Pain and epithelialization rates between standard and applicator treatment methods did not differ statistically significantly over the treatment period.

\section{Introduction}

Second-degree burns involve all of the epidermis and part of the underlying dermis. Superficial partial-thickness burns damage the upper layers of the papillary dermis; they are identified by clear blisters and weeping, wet, erythematous skin, and they blanch painfully when touched $[1,2]$. Partial skin thickness superficial burns are characterized by good regeneration due to the remaining cultures of healthy keratinocytes in the deeper layers of the skin - hair follicles, sebaceous and sweat glands [3]. These burns heal within two weeks and generally do not cause scarring; however, scarring and pigment changes are possible $[1,2]$. 
It is advisable to use antimicrobial ointments for wound care before epithelialization. The most common drug in practice is silver sulfadiazine cream. The drug protects the burn wound from drying out and infection. The cream is applied generously on the burns, sterile gauze bandages are applied on top. Considered daily. Modern bandages can be used: hydrocolloid, hydrofiber bandages, polyurethane bandages with a silicone membrane. Such bandages maintain an optimal environment for wound healing, effectively absorb exudate, change less frequently than the usual bandage, every 3-5 days, do not damage the newly recovered epidermis during the change. When partial skin thickness superficial burns heal, skin care products that moisturize and nourish the skin surface are recommended [4].

In the case of deep burns of part of the skin thickness, a clinically visible necrosis peel that gives the wound surface a bright red or gray matte color. The burn surface tends to bleed less compared to the superficial burn of part of the skin thickness. The sensory nerve endings are partially destroyed, so the pain when touching such a burn is also less. Microscopically, the entire teat and retinal part of the dermis is covered by coagulation necrosis. Keratinocytes in the hair follicles and sweat glands remain intact only in the deep layers of the dermis. These cells, and thus the keratinocytes at the edges of the wound, become spontaneous sources of epithelialization, which under favorable conditions IIB $^{\circ}$ burns heal spontaneously within 3-4 weeks. Changes in skin pigmentation and hypertrophic scarring may occur in the area of burns $[3,5]$.

If deep burns of part of the skin thickness cover $<10 \%$ of the total body surface area (TBSA), the authors recommend the removal of damaged tissues by mechanical dermabrasion and conservative treatment with hydrocolloid dressings. The area of the lesion in this case is small, there is no residual large amount of necrosis in the body, there is no systemic toxicity. In the right environment, supported by hydrocolloid bandages, rapid epithelialization of burns from the edges of the wound takes place and the deeper layers of the skin are not damaged. If the burn area is 10 to 20 percent of the TBSA, the choice of treatment tactics depends on the depth of the burn. Where there are mixed superficial and deep burns of part of the skin thickness, mechanical dermabrasion and bandage treatment or bandage treatment only are appropriate. If the epithelialization process is insufficient during treatment, necrectomy and transplantation of part of the skin graft is appropriate. If the burn area is $>20 \%$ of the TBSA, the author recommends necrectomy and autodermoplasty for all deep burns of part of the skin thickness, because in such conditions the ability of tissues to regenerate is reduced. In such a situation, wound necrosis can lead to serious complications, the body is not able to perform autolysis well enough, burn healing is prolonged, complicated by hypertrophic scarring and contractures [6].

Treatment of patients with burns is associated with high expenses and long hospitalization. In this regard the usage of the local treatment physical products for the cure of the thermal wound is in great interest.

The strategies of regenerative medicine based on small molecules, biomimetic scaffolds, gene or cell therapy, and electromagnetic field manipulation represent some of the modern therapeutic alternatives for wound healing. [7]. Ability of electromagnetic fields (EMF) to stimulate cell proliferation and differentiation has attracted the attention of many laboratories specialized in regenerative medicine over the past number of decades. Recent studies have shed light on bio-effects induced by the EMF and how they might be harnessed to help control tissue regeneration and wound healing. Number of recent reports suggests that EMF has a positive impact at different stages of healing. Processes impacted by EMF include, but are not limited to, cell migration and proliferation, expression of growth factors, nitric oxide signaling, cytokine modulation, and more [8].

The EMF represent a form of non-ionizing, low-energy, electromagnetic field radiation capable of inducing physiological effects. [9]. Although the mechanism interaction remains obscure to the end $[10,11]$, therapy with EMFs has been used for quite a long time in several medical therapeutic protocols, and the efficacy of low intensity EMFs has been demonstrated in several clinical applications. Repair stimulation is one of the stronger and better documented biological effects of EMFs [9]. Some cases reported, EMF treatment stimulated early formation of connective tissue and a vascular network, early collagen synthesis and better maturation, all leading to complete re-epithelialization faster [12 - 14].

We decided to evaluate the effectiveness of the external electromagnetic field due matrix to the wound healing process in partial skin thickness (IIA and IIB degree) burns.

Aim: to evaluate the effectiveness of the external electromagnetic field due matrix to the wound healing process in partial skin thickness (IIA and IIB degree) burns.

\section{Patients and methods}

The study was carried out retrospectively in the hospital of Lithuanian University of Health Sciences. We evaluated medical records of 18 patients who underwent treatment in the department of plastic and reconstructive surgery from 2018.01.01 to 2019.12.30. All patients had IIA-IIB degree burns affecting less than $10 \%$ of the body surface and underwent the standard general treatment. They were divided into two groups: control group 55,6\% $(\mathrm{n}=10)$ - treated only with 
the standard treatment and research group $44,4 \%(n=8)$ - to whom the EMF matrix were applied. Every three days all patients underwent standard wound dressing and for research group EMF matrix were applied on the wound dressing. Each time wound inflammation signs (heat, pain, erythema, swelling), exudation, presence of fibrin, granulations and epithelialization process were evaluated. IBM SPSS Statistics 23 was used for statistical analysis. Statistical analysis of nonparametric criteria was used to assess the relationship between treatment methods and wound healing rates. We used the Mann-Whitney criterion for independent samples, and a partial nonparametric (Spearman) correlation coefficient to assess the possible influence of other factors. Due to the limited sample, the Propensity score matching method was not used. The difference in results was considered significant when the criterion of statistical significance was $\mathrm{p}$ $<0.05$, test power $\mathrm{OP}>0.8$

\section{Results}

The analysis showed that the average hospitalization time of the control group was $8.5(0.898)$ days, while in the research group it was 7.88 (1.493) days, no statistically significant difference $(\mathrm{p}>0.05)$. Pain assessment, wound granulation area, and epithelialization were chosen to evaluate

Table 1. Change in burn healing rates over 7 days of treatment using standard and EMF matrix treatment methods.

\begin{tabular}{|c|c|c|c|}
\hline $\begin{array}{l}\text { Burn healing } \\
\text { indicators }\end{array}$ & $\begin{array}{l}\text { Standard } \\
\text { treatment }\end{array}$ & $\begin{array}{c}\text { EMF } \\
\text { matrix }\end{array}$ & \begin{tabular}{|c|} 
Mann- \\
Whitney U; \\
p
\end{tabular} \\
\hline \multicolumn{4}{|c|}{$0+1$ day after hospitalization } \\
\hline Pain $(\mathrm{v} \pm \mathrm{SD})$ & $6,90 \pm 1,595$ & $6,29 \pm 1,704$ & 27,$5 ;, 445$ \\
\hline Granul & & & 31,$5 ;, 718$ \\
\hline $\begin{array}{l}\text { Epithelialization } \\
(\mathrm{v} \pm \mathrm{SD})\end{array}$ & $1,40 \pm 1,075$ & $1,14 \pm 1,345$ & 30,$5 ;, 648$ \\
\hline \multicolumn{4}{|c|}{$3 \pm 1$ day after hospitalization } \\
\hline Pain $(\mathrm{v} \pm \mathrm{SD})$ & $5,60 \pm 1,578$ & $5,29 \pm 1,704$ & 31,$5 ;, 724$ \\
\hline Gra & $50 \pm 0,850$ & $3,29 \pm 0,951$ & 19,$0 ;, 101$ \\
\hline $\begin{array}{l}\text { Epithelialization } \\
(\mathrm{v} \pm \mathrm{SD})\end{array}$ & $2,20 \pm 1,398$ & $1,71 \pm 1,704$ & 29,$5 ;, 582$ \\
\hline \multicolumn{4}{|c|}{$5 \pm 1$ day after hospitalization } \\
\hline Pain (v: & $4,50 \pm 2,138$ & $3,67 \pm 1,633$ & 18,$5 ;, 469$ \\
\hline Granulati & & & 6,$5 ;, 019$ \\
\hline $\begin{array}{l}\text { Epithelialization } \\
(\mathrm{v} \pm \mathrm{SD})\end{array}$ & $2,88 \pm 0,835$ & $3,00 \pm 0,894$ & 22,$0 ;, 784$ \\
\hline \multicolumn{4}{|c|}{$7 \pm 1$ day after hospitalization } \\
\hline & & & 17,$5 ; 1,000$ \\
\hline & & & 13,$0 ;, 445$ \\
\hline $\begin{array}{l}\text { Epithelialization } \\
(\mathrm{v} \pm \mathrm{SD})\end{array}$ & $3,71 \pm 1,113$ & $3,60 \pm 1,140$ & 16,$5 ;, 867$ \\
\hline
\end{tabular}

the burn healing process. These indicators were assessed on day $0-1 ; 3 \pm 1$ days and $7 \pm 1$ days after hospitalization (Table 1).

There was a statistically significant increase in wound granulation 5 days after the start of treatment in patients treated with the applicator $(\mathrm{p}=0.019)$. Pain and epithelialization rates between standard and applicator treatment methods did not differ statistically significantly over the treatment period.

The partial nonparametric Spearman correlation coefficient, eliminating potentially influencing factors such as time after injury, the area of burn showed that the treatment method had a direct effect on the area of wound granulation $(r=0.625 ; p=0.04)$.

\section{Conclusions}

During the period from 2018.01.01 to 2019.12.30, 18 patients were treated for IIA-IIB degree burns affecting less than $10 \%$ of the body surface. $55,6 \%(\mathrm{n}=10)$ - treated only with the standard treatment and research group $44,4 \%(n=8)$ - to whom the EMF matrix were applied. Hospitalization time applying treatment with the applicators was shorter than with standard treatment, but there was no statistically significant difference between the groups. Also, the research did not show the statistically significant difference between the groups comparing inflammation signs, but there was a statistically significant increase in wound granulation 5 days after the start of treatment in patients treated with the applicator $(p=0.019)$. Pain and epithelialization rates between standard and applicator treatment methods did not differ statistically significantly over the treatment period.

We can say that there is a clear trend in our study in the treatment of wounds using the EML matrix, but a larger sample study should be performed to confirm this hypothesis.

\section{References}

1. Pauldine R, Gibson BR, Gerold KB, Milner SM. Considerations in burn critical care. Contemp Crit Care 2008;6(3):1-11.

2. Grunwald TB, Garner WL. Acute burns. Plast Reconstr Surg 2008;121(5):311e-319e. https://doi.org/10.1097/PRS.0b013e318172ae1f

3. Bullocks JM, Hsu PW, Izaddoost SA, Hollier LH, Stal S. Plastic surgery emergencies. Thieme Medical Publishers, Inc. 2008:39-44.

https://doi.org/10.1055/b-002-59211

4. Heimbach DM, Logsetty S. Modern techniques for wound coverage of the thermally injured upper extremity. Hand Clin 2000;16(2):205-214.

5. Rimdeika R. Nudegimų chirurgija. Kaunas: Lietuvos katechetikos centro leidykla, 2002:93. 
6. Kazmierski M, Mankowski P, Jankowski A, Harasymczuk J. Comparison of results of operative and conservative treatment of deep dermal partal-thickness scalds in children. Eur J Pediatr Surg 2007;17:1-8.

https://doi.org/10.1055/s-2006-924646

7. Costin G, Birlea, S, Norris A. Trends in wound repair: cellular and molecular basis of regenerative therapy using electromagnetic fields. Current Molecular Medicine 2012;12(1):14-26(13).

https://doi.org/10.2174/156652412798376143

8. Saliev T, Mustapova Z, Kulsharova G, Bulanin D, Mikhalovsky S. Therapeutic potential of electromagnetic fields for tissue engineering and wound healing. Cell Proliferation 2014;47(6): 485-493

https://doi.org/10.1111/cpr.12142

9. Pesce M, Patruno A, Speranza L, Reale M. Extremely low frequency electromagnetic field and wound healing: implication of cytokines as biological mediators. Eur Cytokine Netw 2013; 24(1):1-10.

https://doi.org/10.1684/ecn.2013.0332

10. Bassett CA, Pawluk RJ, Pilla AA. Augmentation of bone repair by inductively coupled electromagnetic fields. Science 1974; 184:575-7.

https://doi.org/10.1126/science.184.4136.575

11. Ryaby JT. Clinical effects of electromagnetic and electric fields on fracture healing. Clin Orthop 1998;355S:S205-15. https://doi.org/10.1097/00003086-199810001-00021

12. Canedo-Dorantes L, Garcia-Cantù R, Barrera R, et al. Healing of chronic arterial and venous leg ulcers through systemic electromagnetic fields. Arch Med Res 2002;33:281-9. https://doi.org/10.1016/S0188-4409(02)00357-0

13. Callaghan MJ, Chang EI, Seiser N, et al. Pulsed electromagnetic fields accelerate normal and diabetic wound healing by increasing endogenous FGF-2 release. Plast Reconstr Surg 2008; 121(1):130-41.

https://doi.org/10.1097/01.prs.0000293761.27219.84

14. Ahmadian S, Zarchi SR, Bolouri B. Effects of extremely-low frequency pulsed electromagnetic fields on collagen synthesis in rat skin. Biotechnol Appl Biochem 2006;43(Pt 2):71-5. https://doi.org/10.1042/BA20050086

\section{ELEKTROMAGNETINIO LAUKO MATRIKOS EFEKTYVUMAS DALIES ODOS STORIO NUDEGIMŲ ŽAIZDŲ GYDYMUI$$
\text { R. Česnaitienè, R. Rimdeika }
$$

Raktažodžiai: nudegimai, nudegimų gydymas, gydymas elektromagnetiniu lauku.

\section{Santrauka}

Nudegimai yra viena sunkiausių traumų, kurią per metus patiria maždaug 11 milijonų žmonių visame pasaulyje. Lietuvoje bendras nudegimų skaičius 100000 gyventojų yra apie 200. Gydymas kompleksinis ir sudètingas. Specializuotų nudegimų centrų prioritetinė veikla - paciento būklès stabilizavimas, infekcijos prevencija ir funkcijų atkūrimo optimizavimas reikalauja daug žmogiškujų ir finansinių išteklių. Siekiant pagreitinti gijimą ir sumažinti hospitalizacijos trukmę, ieškoma kuo veiksmingesnių nudegimo gydymo būdų. Pastarojo meto pranešimų skaičius rodo, kad elektromagnetinis laukas (EML) turi teigiamą poveikị įvairiems žaizdų gydymo etapams. EML veikiami procesai apima (bet neapsiriboja) ląstelių migraciją ir proliferaciją, augimo veiksnių ekspresiją, azoto oksido signalizavimą, citokinų moduliaciją ir kt.

Darbo tikslas - ištirti elektromagnetinès matricos poveikį nudegimo žaizdų gijimui. Mes įvertinome 18 pacientų, nuo $2018 \mathrm{~m}$. sausio 1 d. iki 2019 m. gruodžio 30 d. gydytų Plastinès ir rekonstrukcinès chirurgijos skyriuje, medicinos dokumentus. Pacientai, ịtraukti ị tyrimą, buvo gydomi dèl IIA-IIB laipsnio nudegimų, apèmusių mažiau nei 10 proc. kūno paviršiaus ploto. Jie buvo suskirstyti ị dvi grupes: kontrolinè grupè $-55,6 \%(n=10)$, kuriai taikytas standartinis gydymas, ir tyrimo grupe $-44,4 \%(n=8)$, kuriai buvo taikoma EML matrica. Statistinè duomenų analizè atlikta naudojant SPSS 23.0 programinę ịrangą.

Rezultatai. Nudegimo gijimo procesui įvertinti buvo pasirinktas skausmo įvertinimas, žaizdos granuliavimo plotas ir epitelizacija. Šie rodikliai įvertinti $0-1$ hospitalizacijos dieną; praejus $3( \pm 1)$ ir $7( \pm 1)$ dienoms po hospitalizavimo. Aplikatoriumi gydomiems pacientams po 5 dienų nuo gydymo pradžios statistiškai reikšmingai padidèjo žaizdų granuliavimas $(\mathrm{p}=0,019)$. Skausmo ir epitelizacijos dažnis tarp standartinio ir aplikatoriaus gydymo metodų statistiškai reikšmingai nesiskyrė visą gydymo laikotarpį. Dalinis neparametrinis Spearman koreliacijos koeficientas, eliminavus galinčius turèti ịtakos veiksnius, tokius kaip laikas po traumos, nudegimo plotas, parodè, kad gydymo metodas turi tiesiogini poveikị žaizdos granuliacijų plotui $(\mathrm{r}=0,625 ; \mathrm{p}=0,04)$.

Išvada. Analizė parodè vidutinę hospitalizavimo trukmę: kontrolinèje grupejje $8,5(0,898)$ dienos, o tyrimo grupejje $-7,88(1,493)$ dienos. Statistiškai reikšmingo hospitalizavimo trukmès skirtumo nebuvo ( $\mathrm{p}>0,05)$. Aplikatoriumi gydomiems pacientams po 5 dienu nuo gydymo pradžios statistiškai reikšmingai padidejjo žaizdų granuliavimas $(\mathrm{p}=0,019)$. Skausmo ir epitelizacijos dažnis tarp standartinio ir aplikatoriaus gydymo metodų statistiškai reikšmingai nesiskyrè per gydymo laikotarpi.

Adresas susirašinèti: raminta.cesnaitiene@gmail.com

Gauta 2020-09-23 